\title{
Euphorbia characias: Phytochemistry and Biological Activities
}

\author{
Antonella Fais ${ }^{(\mathbb{D}}$, Giovanna Lucia Delogu $+\mathbb{(}$, Sonia Floris, Benedetta Era $\mathbb{B}$, Rosaria Medda *(i) \\ and Francesca Pintus (D)
}

Citation: Fais, A.; Delogu, G.L.;

Floris, S.; Era, B.; Medda, R.; Pintus, F. Euphorbia characias: Phytochemistry and Biological Activities. Plants 2021, 10, 1468. https://doi.org/10.3390/ plants10071468

Academic Editors:

Antonella Smeriglio and

Sebastian Granica

Received: 10 June 2021

Accepted: 13 July 2021

Published: 17 July 2021

Publisher's Note: MDPI stays neutral with regard to jurisdictional claims in published maps and institutional affiliations.

Copyright: (c) 2021 by the authors. Licensee MDPI, Basel, Switzerland. This article is an open access article distributed under the terms and conditions of the Creative Commons Attribution (CC BY) license (https:/ / creativecommons.org/licenses/by/ $4.0 /)$.
Department of Life and Environmental Sciences, University of Cagliari, Monserrato, 09042 Cagliari, Italy; fais@unica.it (A.F.); delogug@unica.it (G.L.D.); s.floris@unica.it (S.F.); era@unica.it (B.E.); fpintus@unica.it (F.P.)

* Correspondence: rmedda@unica.it

t These authors contributed equally to this work.

Abstract: The aim of this review is to summarize all the compounds identified and characterized from Euphorbia characias, along with the biological activities reported for this plant. Euphorbia is one of the greatest genera in the spurge family of Euphorbiaceae and includes different kinds of plants characterized by the presence of milky latex. Among them, the species Euphorbia characias L. is an evergreen perennial shrub widely distributed in Mediterranean countries. E. characias latex and extracts from different parts of the plant have been extensively studied, leading to the identification of several chemical components such as terpenoids, sterol hydrocarbons, saturated and unsaturated fatty acids, cerebrosides and phenolic and carboxylic acids. The biological properties range between antioxidant activities, antimicrobial, antiviral and pesticidal activities, wound-healing properties, anti-aging and hypoglycemic properties and inhibitory activities toward target enzymes related to different diseases, such as cholinesterases and xanthine oxidase. The information available in this review allows us to consider the plant E. characias as a potential source of compounds for biomedical research.

Keywords: Euphorbia characias; plant extracts; phytochemical constituents; biological activities

\section{Introduction}

Euphorbiaceae is one of the largest flowering plant families, which is widely distributed in the world, especially in the tropical and temperate regions, and comprises about 300 genera and 8000 species [1]. The classification of Euphorbiaceae was revealed to be difficult due to the variability of habitat, morphology and genetics. This family showed a rich variety of chemical substances, especially rich in alkaloids and terpenoid compounds, and several potentially medicinal properties [2,3]. The genus Euphorbia comprises different kinds of plants, such as trees, lianas, herbs and shrubs. These plants are characterized by the presence of milky latex sap contained inside the laticifers, single specialized cells or articulated series of cells that permeate various tissues of the plant. Latex is a complex emulsion which consists of lipids, rubber, resin, starch and a variety of different proteins and enzymes. The physiological function of the latex is not completely known but it probably has a role as a water and nutrition reserve, and it seems to be involved in plant defense against phytopathogens and in sealing wounded areas [4].

Among Euphorbiaceae, the species Euphorbia characias L. is an evergreen perennial shrub up to about $1.5 \mathrm{~m}$ tall, with a bushy habit, widely distributed in Mediterranean countries. The inflorescence has a unique structure called the 'cyathia' which is arranged in rays growing from the bases of leaves. Leaves have a lanceolate structure $15 \mathrm{~cm}$ long, arranged along the stems. Latex permeates through all the plant and mainly exudes from the cut stems (Figure 1). 

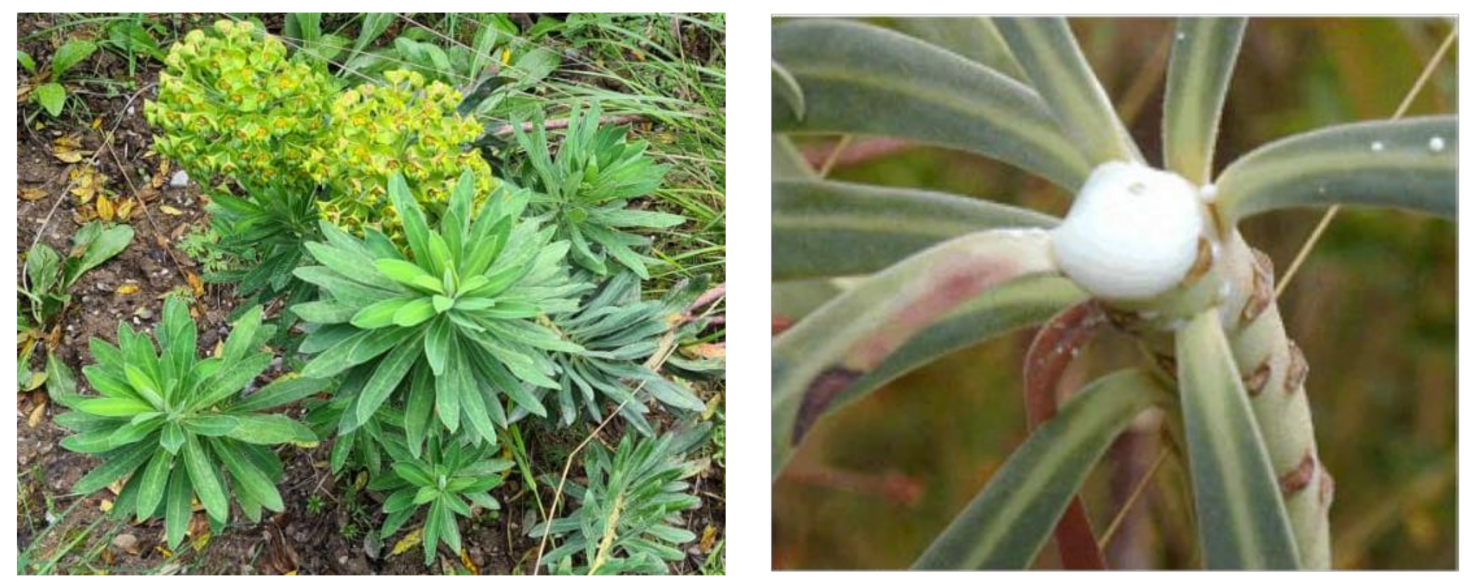

Figure 1. The Mediterranean shrub E. characias. Leaves and characteristic flowers are visible in the imagine on the left (a), while (b) clearly shows the milky latex that exudes from the cut branch of the plant (imagine modified from reference [4]).

E. characias latex has been extensively studied and several proteins have been isolated and characterized. Among them, an enzyme named Euphorbia latex peroxidase (ELP) has been the object of numerous research papers due to its peculiar characteristics. This is a calmodulin-binding protein and its activity is therefore finely regulated by calcium ions. The presence of these ions, in addition to increasing the enzymatic activity, can even direct ELP towards different catalytic pathways using the same substrate [5]. A copper/TPQcontaining amine oxidase is also a part of the complex machinery of E. characias latex and the characterization of this enzyme made it possible to discover the key role of specific amino acids and domains in modulating substrate access into the active site of plant and mammalian amine oxidases [6]. Moreover, other enzymes have been purified and characterized and several nucleotide sequences are present in the GenBank database [7-9].

In recent years, scientists have made a great contribution to reporting the chemical constituents and biological properties of E. characias. However, there is no systematic review available that covers the important aspects of this plant, such as its non-protein composition. In order to provide new information for in-depth exploration and full use of this plant, we systematically and critically summarized the current findings on the non-protein compounds identified and characterized from E. characias. Furthermore, the biological activities of the isolated compounds or the tested extracts are also reported. The information available on this plant, reported in this review, allows us to explore their therapeutic potential, highlight gaps and provide the scientific basis for future study of this plant.

\section{Chemical Constituents}

Many chemical compounds with different structures have been identified and isolated from E. characias. In the following subsections, all these compounds, together with their nomenclature, are reported. The chemical structure of most of the compounds is reported to get an overview of the compounds with the structure immediately available, avoiding the well-known structure of compounds such as sugars, alkanes, alkenes or fatty acids. The reported molecules were identified from different parts of the plant (for example, in leaves, stems, latex, flowers or seeds) and the localization of each compound is also reported.

\subsection{Terpenoids, Sterol Hydrocarbons, Fatty Acids and Cerebrosides}

Terpenes are a class of hydrocarbon secondary metabolites, and their structure is built up from five-carbon isoprene units linked together. A rich diversity of structural classes of terpenes depend on different configuration degrees of unsaturation, oxidation, ring closures and functional groups. Terpenoids are primarily found in a wide variety of higher plants [10]. The terpenes and terpenoids are classified in hemiterpenes (1), 
monoterpenes (2), sesquiterpenes (3), diterpenes (4), sesterterpenes (5), triterpenes (6) and polyterpenes (many units), based on the number of isoprene units they present.

Polycyclic diterpenoids have been found in several plants of Euphorbia species and represent one of the major components of the lipid fraction [11]. In 2000, Appendino and colleagues identified 13 oxygenated diterpenoids from E. characias [12]. These compounds were isolated from an acetone extract from leaves and stems of the plant. Moreover, another two diterpenoid compounds were identified in the hexane extract of the latex. Table 1 shows the structure of these compounds which are abietane (compounds 1-6), atisane (compounds 7-9), kaurene (compound 10), pimarane (compounds 11-13) and cembrane (compound 15)type diterpenoids. Diterpenes are important as natural products for potential applications as pharmacological agents in drug discovery due to their wide range of biological activities. In fact, antitumor, antimicrobial and anti-inflammatory activities are only some of the reported biological activities of this class of molecules [13]. Helioscopinolides A (4) and B (5) have displayed relevant activity against Staphylococcus aureus and a modest antibacterial property against Moraxella catarrhalis was previously found for helioscopinolide A [14]. Moreover, the ent-abietane compounds showed meaningful up-regulated expressions of matrix metalloproteinases [15], which not only have a role in the resolution phase of wound healing but also affect other responses linked to wound healing, such as re-epithelization and inflammation [16]. In a previous work [17], compound 10 (16ß,17-dihydroxy-entkauran-3-one) was found to be cytotoxic at concentrations ranging from 2 to $50 \mu \mathrm{g} / \mathrm{mL}$.

Table 1. Diterpenoids identified from aerial parts (leaves and stems) (compounds 1-10, 12-14) [12] and latex (compounds 11,15) [18] of E. characias: structure of ent-abietanes, ent-atisanes, ent-kauranes, ent-pimaranes and cembrene.

\begin{tabular}{|c|c|}
\hline Structure & Compound \\
\hline \multicolumn{2}{|c|}{ ent-abietanes-1 } \\
\hline & $\begin{array}{c}18 \alpha, 14 \text {-dihydro-7-oxojolkinolide } \mathrm{E} \\
\mathrm{R}=\mathrm{H}\end{array}$ \\
\hline & $\begin{array}{c}2 \text { caudicifolin } \\
\mathrm{R}=\mathrm{OH} \\
(8 \alpha, 14 \text {-dihydro-7-oxohelioscopinolide } \mathrm{A})\end{array}$ \\
\hline \multicolumn{2}{|c|}{ ent-abietanes-2 } \\
\hline & $\begin{array}{c}3 \text { jolkinolide } \mathrm{E} \\
\mathrm{R}_{1}=\mathrm{R}_{2}=\mathrm{H} \\
\text { (ent-abieta-8(14),13(15)-dien-16,12-olide) }\end{array}$ \\
\hline & $\begin{array}{l}4 \text { helioscopinolide } \mathrm{A} \\
\mathrm{R}_{1}=\mathrm{OH} ; \mathrm{R}_{2}=\mathrm{H}\end{array}$ \\
\hline $\mathrm{R}_{2}$ & $\begin{array}{c}5 \text { helioscopinolide } B \\
\mathrm{R}_{1}=\mathrm{H} ; \mathrm{R}_{2}=\mathrm{OH}\end{array}$ \\
\hline
\end{tabular}

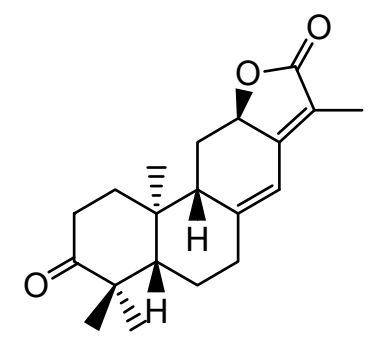

6 helioscopinolide E 
Table 1. Cont.

Compound
ent-atisanes

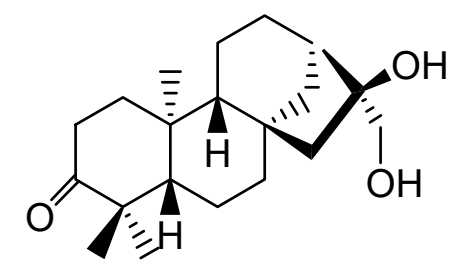

ent-kauranes

10 16 3 ,17-dihydroxy-ent-kauran-3-one<smiles>C=C1C[C@]23CC[C@@H]4C(C)(C)CCC[C@]4(C)[C@H]2CC[C@H]1C3</smiles>

ent-pimaranes

11 kaurene<smiles>C=C[C@@]1(C)C=C2CC[C@H]3[C@@H](C)[C@H](O)CC[C@@]3(C)[C@]2(C)CC1</smiles>

12 ent-pimara-8(14),15-dien-3 $\alpha$-ol



$\mathrm{R} \mathrm{R}_{1}$

13 3 $\beta, 15,16$-triacetoxy-ent-pimar-8(14)-ene $\mathrm{H} \mathrm{OAc}$ 14 3 $\beta, 15$,16-triacetoxy-ent-pimar-8(14)-en-2-one $\mathrm{C}=\mathrm{O}$ OAc

\section{cembranes}

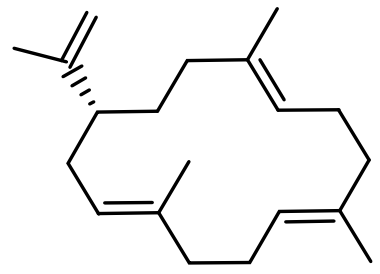

15 cembrene 
In 1983 and in 1984, Seip and Hecker isolated different lathyrane (16a-f) and jatrophanetype (17a-h) compounds from the acetone extract of E. characias latex $[19,20]$, and the relative structures are reported in Table 2.

Lathyranes represent one of the main groups of tricyclic diterpenes with a 5,11 and 3membered ring system. These diterpenes may be considered derived from the hydrocarbon nucleus of casbane and its unsaturated analogue casbene. The fusion of rings $A$ and $B$ may have the configuration trans or cis; usually trans between rings A and B and cis between B and C. They may contain an epoxy function and double bonds.

Jatrophane diterpeses are macrocyclic compounds with a bicyclo[10.3.0]pentadecane skeleton, without the cyclopropane ring of lathyranes. Their structures vary for the configuration of the diterpene core, the number and position of the double bonds and the number of oxygen functions, which can be hydroxy, keto, epoxy, ether and ester groups. Natural jatrophane diterpenes, occurring exclusively in the Euphorbiaceae family, are in general polyacylated derivatives in which the acetyl, benzoyl, isobutanoyl, 2-methylbutanoyl or nicotinoyl are the acyl residues most frequently bounded.

Twelve new diterpenes were isolated from the whole plant. These compounds are based on a jatrophane skeleton and named euphocharacins a-l (18a-1) (Table 2) [21]. The biological activity of these compounds isolated from an ethyl acetate extract is reported as inhibition of the daunomycin-efflux activity of P-glycoprotein from cancer cells [22].

Triterpenes are also predominant structures among the secondary metabolites identified in latex extract. Cycloartenol (21), 24-methylenecycloartenol (22), lanosterol (24) and lupeol (28) were found in significant amounts, but the major constituent was butyrospermol (25). Obtusifoliol (31), ergostadienol (32) and squalene (19) were present but in lower quantities. In the category of sesquiterpenes, cedrene (33), junipene (34), cadinene (35) and germacrene (36) were also identified [18]. Squalene and its derivatives, as well as other sterol compounds, were also identified in extracts from other sources, as reported in Figure 2.

Table 2. Lathyranes and jatrophanes identified from E. characias latex (compounds 16a-f and 17a-f) [19,20], roots (compounds $\mathbf{1 7 g}-\mathbf{h}$ ) and whole plant (compounds 18a-1) [21].

\begin{tabular}{|c|c|}
\hline Scheme & Compound \\
\hline \multicolumn{2}{|c|}{ lathyranes } \\
\hline $\mathrm{R}_{1} \mathrm{O}$ &  \\
\hline
\end{tabular}

jatrophanes

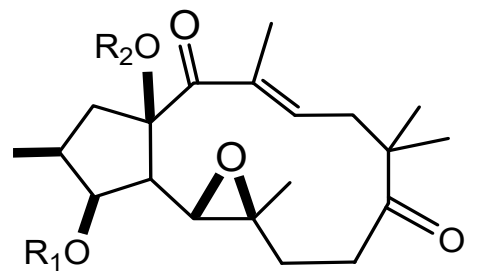

17a 15-O-acetyl-3-O-tigloylcharaciol-5 $\beta, 6 \beta$-oxide)

$\mathrm{R}_{1}=$ tigloyl (COC $\left.(\mathrm{Me}){ }_{-}^{\mathrm{E}} \mathrm{CHMe}\right) ; \mathrm{R}_{2}=\mathrm{COCH}_{3}$;

17b 15-O-acetyl-3-O-benzoylcharaciol-5 $\beta, 6 \beta$-oxide) $\mathrm{R}_{1}=$ benzoyl $\left(\mathrm{COC}_{6} \mathrm{H}_{5}\right) ; \mathrm{R}_{2}=\mathrm{COCH}_{3}$ 
Table 2. Cont.

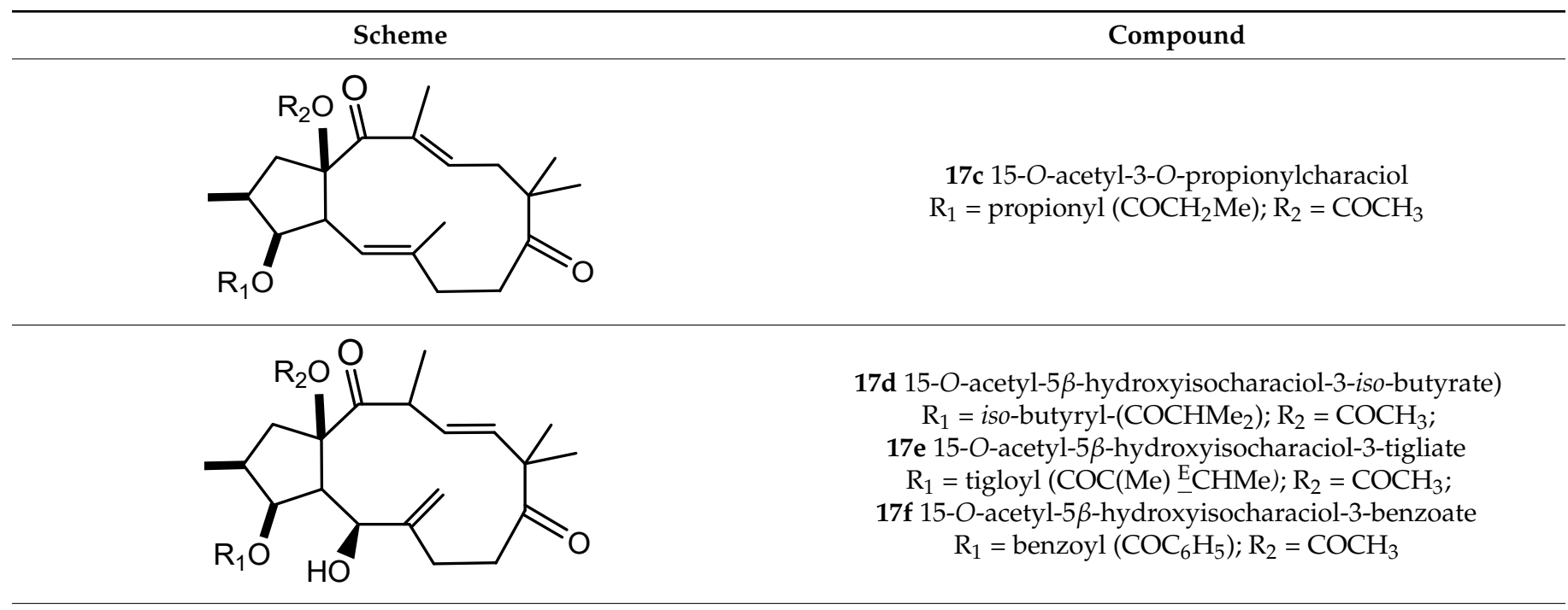

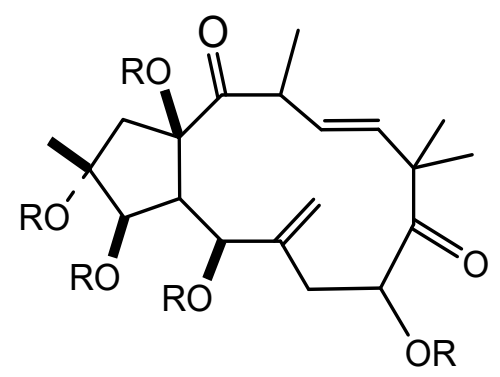

$17 \mathrm{~g}$ 2,5,8,15-O-triacetyl,

nicotinoyl-2,5 $\beta, 8$-trihydroxyisocharaciol-3-benzoate $\mathrm{R}=$ acetyl (x 3), benzoyl, nicotinoyl;

17h 2,5,8,15-O-triacetyl,

nicotinoyl-2,5 $\beta, 8$-trihydroxyisocharaciol-3-tigliate $\mathrm{R}=$ acetyl (x 3), tigloyl, nicotinoyl;

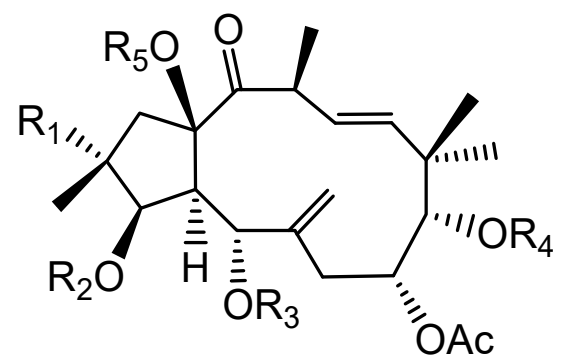

18a-l euphocharacin

18a $\mathrm{R}_{1}=\mathrm{OH} ; \mathrm{R}_{2}=\mathrm{Bz} ; \mathrm{R}_{3}=\mathrm{Ac} ; \mathrm{R}_{4}=\mathrm{Nic} ; \mathrm{R}_{5}=\mathrm{Ac}$ $18 b R_{1}=O H ; R_{2}=B z ; R_{3}=A c ; R_{4}=N i c ; R_{5}=H$

$18 \mathrm{c} \mathrm{R}_{1}=\mathrm{OH} ; \mathrm{R}_{2}=\mathrm{Bz} ; \mathrm{R}_{3}=\mathrm{Ac} ; \mathrm{R}_{4}=\mathrm{Bz} ; \mathrm{R}_{5}=\mathrm{H}$

$18 d R_{1}=\mathrm{OH} ; \mathrm{R}_{2}=\mathrm{MeBu} ; \mathrm{R}_{3}=\mathrm{Ac} ; \mathrm{R}_{4}=\mathrm{Nic} ; \mathrm{R}_{5}=\mathrm{Ac}$

18e $R_{1}=H ; R_{2}=B z ; R_{3}=A c ; R_{4}=N i c ; R_{5}=H$

$18 f \mathrm{R}_{1}=\mathrm{H} ; \mathrm{R}_{2}=\mathrm{Bz} ; \mathrm{R}_{3}=\mathrm{Ac} ; \mathrm{R}_{4}=\mathrm{Nic} ; \mathrm{R}_{5}=\mathrm{Ac}$

$18 \mathrm{~g} \mathrm{R}$ = H; $\mathrm{R}_{2}=i \mathrm{Bu} ; \mathrm{R}_{3}=\mathrm{Ac} ; \mathrm{R}_{4}=\mathrm{Nic} ; \mathrm{R}_{5}=\mathrm{H}$

$18 \mathrm{~h} \mathrm{R}_{1}=\mathrm{H} ; \mathrm{R}_{2}=i \mathrm{Bu} ; \mathrm{R}_{3}=\mathrm{Ac} ; \mathrm{R}_{4}=\mathrm{Nic} ; \mathrm{R}_{5}=\mathrm{Ac}$

$18 \mathbf{i} R_{1}=H ; R_{2}=$ Pr; $R_{3}=A c ; R_{4}=N i c ; R_{5}=A c$

18j $R_{1}=H ; R_{2}=A c ; R_{3}=A c ; R_{4}=N i c ; R_{5}=A c$

18k $\mathrm{R}_{1}=\mathrm{H} ; \mathrm{R}_{2}=i \mathrm{Bu} ; \mathrm{R}_{3}=\mathrm{H} ; \mathrm{R}_{4}=\mathrm{Nic} ; \mathrm{R}_{5}=\mathrm{Ac}$

$181 \mathrm{R}_{1}=\mathrm{OH} ; \mathrm{R}_{2}=\mathrm{Bz} ; \mathrm{R}_{3}=\mathrm{H} ; \mathrm{R}_{4}=\mathrm{Nic} ; \mathrm{R}_{5}=\mathrm{Ac}$

$\mathrm{Pr}=$ propionyl; $i \mathrm{Bu}=$ isobutiryl; $\mathrm{MeBu}=2$-methylbutiryl; $\mathrm{Bz}=$ benzoyl;

$\mathrm{Nic}=$ nicotinoyl

In seeds of E. characias, the major lipids are neutral lipids, most of which are triacylglycerols, representing $80-97 \%$ of the total lipids [23]. The fatty acids identified in E. characias were myristic, palmitic, palmitoleic, stearic, oleic, vaccenic, linoleic, linolenic and arachidic acid (compounds 38-46) [23-26]. Considering the literature, the published data about fatty acids composition present slightly differences, but it is clear that unsaturated fatty acids are more dominant than saturated in seeds $[23,24]$. Leaves showed a higher presence of linolenic acid (18:3) [23,25]. Moreover, oleic acid (18:1) is the major component of elaiosome and a role of this fatty acid in myrmecochory, by acting as a chemical cue for ants, has been proposed [26]. 

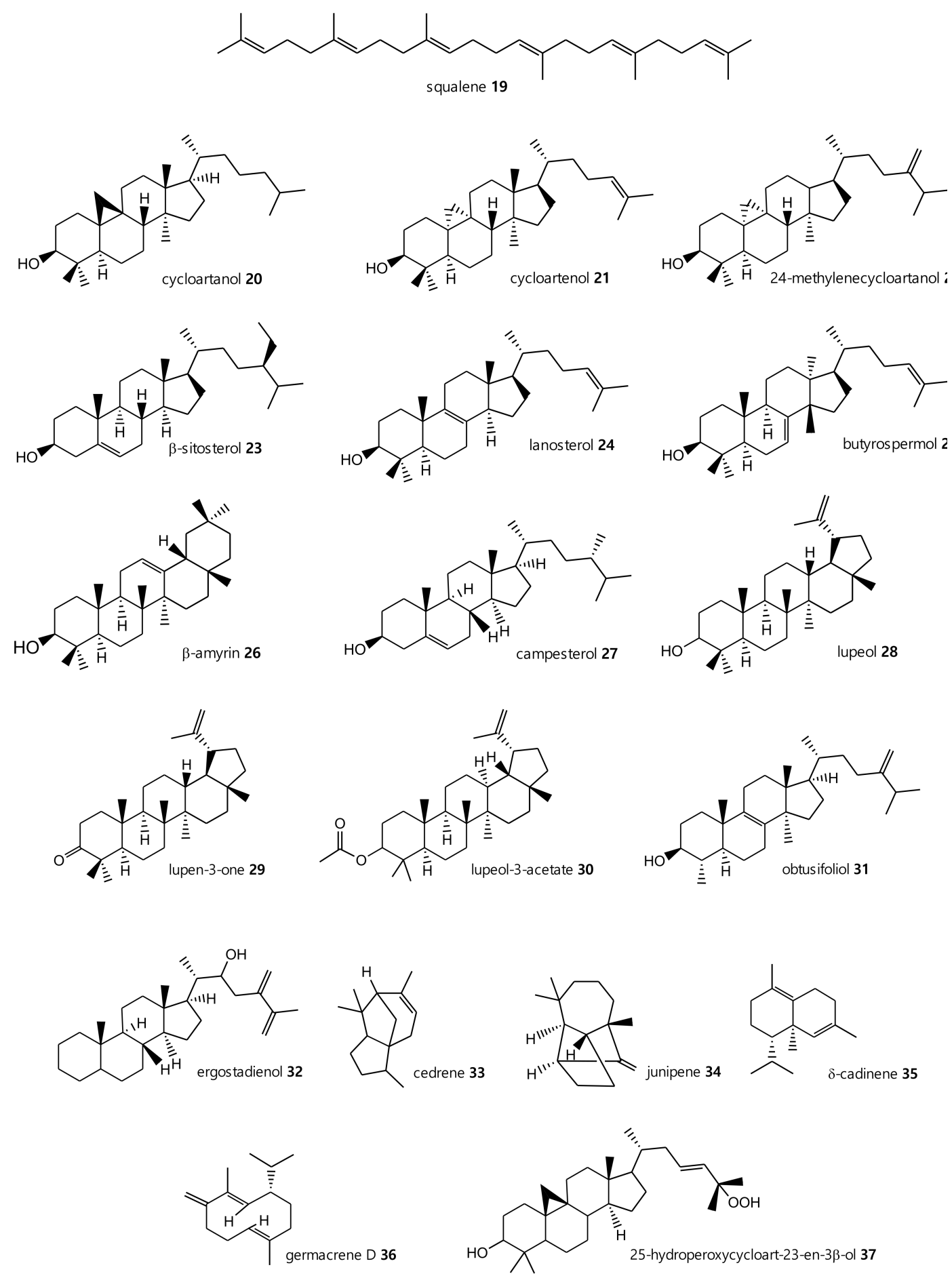

Figure 2. Triterpenes, sterols and sesquiterpenes identified from E. characias latex (compounds 19, 20, 22, 24, 25, 28, 31-36) [18], seeds (compounds 20, 22-24, 26, 27) [24] and aerial parts (compounds 19-26, 28-30, 35-37) [25,27].

Cerebrosides represent a member of the sphingolipid class of lipids, which are also known to be distributed in Euphorbiaceae latex.

Nine cerebrosides were isolated and purified from the latex of E. characias (compounds 47-55) (Table 3). Structurally, these cerebrosides are composed of a 1-O- $\beta$-Dglucopyranoside linked to a polyhydroxy sphingosine and a 2-hydroxy saturated or unsaturated fatty acid. 
Table 3. Cerebrosides identified from the latex of E. characias (compounds 47-55).

cerebrosides $47-50[28]$

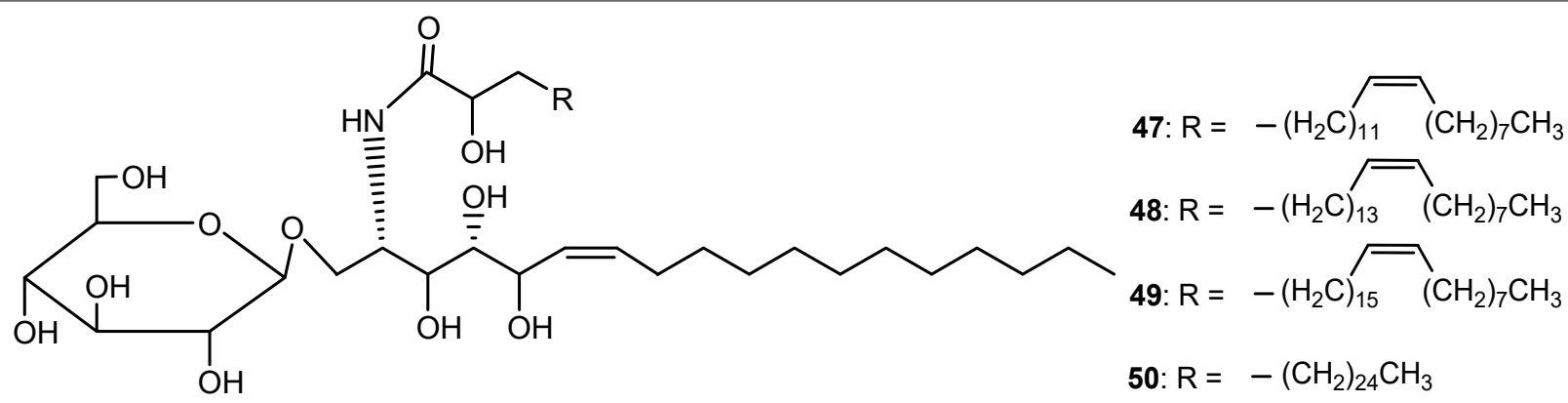

47 (2S, 3S, 4R, 5R, 6Z)-1-O-( $\beta$-D-glucopyranosyl)-2-N-[2'R)-2'-hydroxy-(15'Z)-tetracosenoylamino]-6(Z)-octadecene-1,3,4,5-tetraol 48 (2S, 3S, 4R, 5R, 6Z)-1-O-( $\beta$-D-glucopyranosyl)-2-N-[(2'R)-2'-hydroxy-(17'Z)-hexacosenoy1amino]-6(Z)-octadecene-1,3,4,5-tetraol 49 (2S, 3S, 4R, 5R, 6Z)-1-O-( $\beta$-D-glucopyranosyl)-2-N-[(2'R)-2'-hydroxy-(19'Z)-octacosenoylamino]-6(Z)-octadecene-1,3,4,5-tetraol 50 (2S, 3S, 4R, 5R, 6Z)-1-O-( $\beta$-D-glucopyranosyl)-2-N-[(2'R)-2'-hydroxyoctacosanoylamino]-(Z)-octadecene-l,3,4,5-tetraol cerebrosides 51-55 [29]

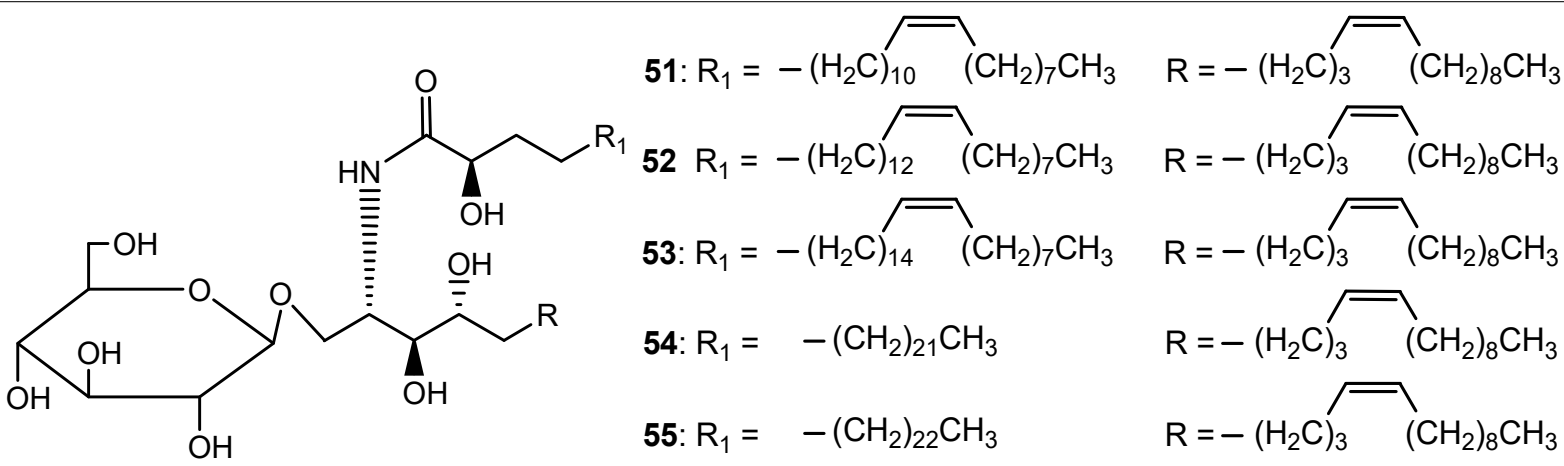

51 (2S, 3S, 4R, 8Z)-1-O-( $\beta$-D-glucopyranosyl)-2-N-[(2'R)-2'-hydroxy-(15'Z)-tetracosenoylamino]-8(Z)-octadecene-1,3,4-triol 52 (2S, 3S, 4R, 8Z)-1-O-( $\beta$-D-glucopyranosyl)-2- $N$-[(2'R)-2'-hydroxy-(17'Z)-hexacosenoyl]-8(Z)-octadecene-1,3,4-triol

53 (2S, 3S, 4R, 8Z)-1-O-( $\beta$-D-glucopyranosyl)-2-N-[(2'R)-2'-hydroxy-(19'Z)-octacosenoylamino]-8(Z)-octadecene-1,3,4-triol 54 (2S, 3S, 4R, 8Z)-1-O-( $\beta$-D-glucopyranosyl)-2- $N$-[(2'R)-2'-hydroxyhexacosanoylamino]-8(Z)-octadecene-1,3,4-triol 55 (2S, 3S, 4R, 8Z)-1-O-( $\beta$-D-glucopyranosyl)-2-N-[(2'R)-2'-hydroxyheptacosanoylamino]-8(Z)-octadecene-1,3,4-triol

\subsection{Phenolic and Carboxylic Acid Compounds}

Phenolic and polyphenolic compounds are a large group of chemical substances with various chemical structures and activities. Chemically, they contain an aromatic ring with one or more hydroxyl groups, and they comprise simple molecules, such as phenolic acids, and more complex compounds, such as flavonoids. Phenolic and polyphenolic compounds are widely disseminated in the plant kingdom and constitute one of the most significant groups of secondary metabolites of plants, showing numerous bioactive properties, the most important being the antioxidant activity.

The chromatographic profile of a trichloroacetic acid (TCA) E. characias latex extract showed the presence of several carboxylic acids (aromatic and aliphatic) and alcoholic compounds [30]: benzoic acid (56), cinnamic acid (57), 4-hydroxybenzylalcohol (58), tyrosol (59), vanillic acid (60), $p$-coumaric acid (61), ferulic acid (62), sinapic acid (63), caffeic acid (64), 2-hydroxypropanoic acid (65), 2,3-dihydroxypropanoic acid (66), 3-hydroxypropanoic acid (67), 2-hydroxy-3-methylbutanoic acid (68), 4-hydroxybutanoic acid (69), 2-hydroxyesanoic acid (70), 3-phenylpropenoic acid (71) and 3-hydroxy-3-phenylpropenoic acid (72). 
Furthermore, some flavonoids were identified in latex but especially in aerial parts of the plant. Flavonoids represent one of the major and ubiquitous pigments in plants. They are composed of two aromatic rings (A and B) linked by an oxygenated heterocycle (C).

These secondary metabolites were mainly quercetin glycosides: quercetin-3-O-glucoside, quercetin-3-xyloside, quercetin-3-arabinoside, quercetin-3-rhamnoside (quercitrin), quercetin3-(2-O-acetyl)arabinofuranoside, quercetin-3-O-galactoside and their precursor quercetin (74-80) (Figure 3). Other compounds, such as gallic acid, catechin, myricetin derivatives and ellagic acid derivatives, were identified in E. characias ethanolic extracts from leaves. Quercetin-3-(2-O-acetyl)arabinofuranoside (79) was the most abundant compound in ethanolic extract of both leaves and flowers, followed by quercetin-3-O-rhamnoside and quercetin-3-O-arabinoside (78,77) [31,32].<smiles>O=C1c2c(O)cc(O)cc2OC(c2cc(O)c(O)c(O)c2)C1O</smiles><smiles>O=c1c(O[C@@H]2OC[C@@H](O)[C@H](O)[C@H]2O)c(-c2ccc(O)c(O)c2)oc2cc(O)cc(O)c12</smiles>
quercetin-3-O-arabinoside 77 ( guaijaverin)<smiles>O=c1c(O)c(-c2ccc(O)c(O)c2)oc2cc(O)cc(O)c12</smiles>

quercetin 74<smiles>COC(=O)OCc1ccc(-c2oc3cc(O)cc(O)c3c(=O)c2O[C@@H]2O[C@H](CO)[C@@H](O)[C@H](O)[C@H]2O)cc1O</smiles>
quercetin-3-O-glucoside 75
(isoquercetin)<smiles>CC(=O)O[C@@H]1[C@@H](O)[C@@H](CO)O[C@@H]1Oc1c(-c2ccc(O)c(O)c2)oc2cc(O)cc(O)c2c1=O</smiles>

quercetin-3-( 2-O-acetyl)<smiles>O=c1c(OC2OC[C@@H](O)[C@H](O)[C@H]2O)c(-c2ccc(O)c(O)c2)oc2cc(O)cc(O)c12</smiles>

quercetin-3-O-xyloside 76<smiles>C[C@H]1O[C@H](Oc2c(-c3ccc(O)c(O)c3)oc3cc(O)cc(O)c3c2=O)[C@H](O)[C@@H](O)[C@H]1O</smiles>

quercetin-3-O-rhamnoside 78 ( quercitrin)<smiles>O=c1c(O[C@@H]2O[C@H](CO)[C@@H](O)[C@H](O)[C@H]2O)c(-c2ccc(O)c(O)c2)oc2cc(O)cc(O)c12</smiles>

quercetin-3-O-galactoside $\mathbf{8 0}$ ( hyperoside)<smiles>O=C(O)c1cc(O)c(O)c(O)c1</smiles><smiles>O=c1c(OP)c(-c2cc(O)c(O)c(O)c2)oc2cc(O)cc(O)c12</smiles><smiles>CC(=O)/C=C/c1ccc(O)c(O)c1</smiles><smiles>O=C1Oc2c(O)c(O)cc3c2c(=O)oc2c(O)c(O)cc1c23</smiles>



86 elagic acid 85 3,3'-dimethyl ellagic acid $\mathrm{R}=\mathrm{H} ; \mathrm{R}_{1}=\mathrm{H} ;$
3,3'-dimethyl ellagic acid pentose $\mathrm{R}=\mathrm{H} ; \mathrm{R}_{1}=$ pentos $\begin{aligned} 3,3^{\prime} \text {-dimethyl ellagic acid deoxyhexose } R=H ; R_{1}=\text { deoxyhexose } & \end{aligned}$<smiles>O=c1c2ccc(OC3OCC(O)C(O)C3O)c(-c3ccc(O)cc3)c2oc2cc(O)cc(O)c12</smiles>

kaempferol-3-O-arabinoside 88

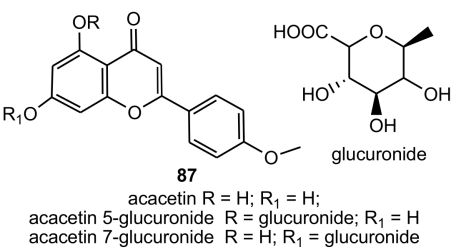

acacetin 5-glucuronide $R=$ glucuronide; $R_{1}=H$
acacetin 7 -glucuronide $R=H ; R_{1}=$ glucuronide

Figure 3. Phenolic compounds identified from E. characias latex (compounds 73, 74) [30] and aerial parts (compounds 74-89) [25,31-33]. 
Wound-healing activity was reported for the methanolic extract of the aerial parts of E. characias subsp. wulfenii [33]. The combined activity of the constituents present in the extract, especially flavonoids such as guaijaverin $\mathbf{7 7}$, quercitrin $\mathbf{7 8}$ and hyperoside $\mathbf{8 0}$, seemed to be responsible of this effect. Biological activities of ethanolic extracts from leaves and flowers were also reported (see Section 3).

Finally, in the aerial parts of the plant, alkanes (90-101), alcohols (102-107), aldehydes (108-113), ketones $(114,115) \alpha$-tocopherol $(116)$, carboxylic acids $(117,118)$ and sugars $(\mathbf{1 1 9}, \mathbf{1 2 1})$ were also identified (Table 4). Several of these metabolites change their concentrations in relation to the three phenological stages of the plant (preflowering, flowering and postflowering).

Table 4. Other compounds (90-121) identified from aerial parts of E. characias.

\begin{tabular}{|c|c|c|}
\hline Compound & Part of the Plant & Reference \\
\hline heptacosane 90 & Stems & [25] \\
\hline nonacosane 91 & \multirow{5}{*}{ Leaves, Stems } & \multirow{5}{*}{ [25] } \\
\hline pentacosene 92 & & \\
\hline hentriacontane 93 & & \\
\hline triacontane 94 & & \\
\hline tritriacontane 95 & & \\
\hline heneicosane 96 & \multirow{6}{*}{ Flowers } & \multirow{6}{*}{ [34] } \\
\hline docosane 97 & & \\
\hline tricosane 98 & & \\
\hline pentacosane 99 & & \\
\hline heptacosane $\mathbf{1 0 0}$ & & \\
\hline nonacosane 101 & & \\
\hline phytol 102 & Leaves, Flowers & {$[25,34]$} \\
\hline tetracosanol 103 & Stems & [25] \\
\hline hexacosanol 104 & \multirow{5}{*}{ Leaves, Stems } & \multirow{5}{*}{ [25] } \\
\hline octacosanol 105 & & \\
\hline inositol 106 & & \\
\hline myo-inositol 107 & & \\
\hline octacosanal 108 & & \\
\hline nonanal 109 & \multirow{7}{*}{ Flowers } & \multirow{7}{*}{ [34] } \\
\hline tridecanal 110 & & \\
\hline tetradecanal 111 & & \\
\hline hexadecanal 112 & & \\
\hline hexacosanal 113 & & \\
\hline 6,10,14-trimethyl-2-pentadecanone 114 & & \\
\hline farnesyl acetone $\mathbf{1 1 5}$ & & \\
\hline$\alpha$-tocopherol 116 & Leaves & [25] \\
\hline hexadecanoic acid 117 & Flowers & [34] \\
\hline pyroglutamic acid 118 & \multirow{4}{*}{ Leaves, Stems } & \multirow{4}{*}{ [25] } \\
\hline D-glucose 119 & & \\
\hline D-fructose 120 & & \\
\hline sucrose 121 & & \\
\hline
\end{tabular}




\subsection{Natural Rubber and Rubber Particles}

Natural rubber is an important polymer produced by numerous plants. The physiological role of rubber is not fully recognized, but it seems to be involved in disease resistance, wound healing or tolerance to environmental stress [35]. The main source of commercial natural rubber, at present, is the latex of Hevea brasiliensis, a member of the Euphorbiaceae family. This rubber has a characteristic high molecular weight ( $>1$ million Da) and properties that are difficult to obtain with synthetic processes. Otherwise, the use of products (gloves or other medical devices) made from this natural rubber could cause an allergic reaction in sensitized persons. Two other plants seem to be a possible alternative to H. brasiliensis: Parthenium argentatum (Guayule) and Taraxacum kok-saghyz. However, new sources of natural rubber are needed [36].

A natural rubber from the latex of E. characias was identified, extracted and characterized [37]. This polymer was extracted by different methods, the better being extraction with acetic acid followed by treatment with cyclohexane and ethanol with a yield of $14.3 \%$ $(w / v)$ of plant latex. It showed a low molecular weight of 93,000 Da and was revealed to have a cis-1,4-polyisoprene structure, typical of natural rubber. This low molecular weight rubber is different to that of $H$. brasiliensis, but it is similar to other Euphorbiaceae, such as Euphorbia etherophylla and Euphorbia lactiflua [38].

In latex-producing plants, the rubber biosynthesis occurs in the latex of laticifers, and rubber is compartmentalized in microscopic rubber particles constituted by a core of rubber encircled by a monolayer membrane and membrane-bound proteins [36]. Rubber particles of $E$. characias are spherical in shape with a diameter ranging from 0.02 to $1.2 \mathrm{~mm}$, as observed by scanning electron microscopy [39]. The membrane-bound cis-prenyltransferase enzyme ("rubber transferase", E.C. 2.5.1.20), which is the key enzyme in natural rubber biosynthesis, was identified in E. characias rubber particles, and the nucleotide and predicted amino acid sequence was determined [39].

\section{Biological Activities}

The biological activities of E. characias extracts are reported in the following subsections. Some extracts showed potential as sources of inhibitors of target enzymes related to different diseases, and the $\mathrm{IC}_{50}$ values are reported in Table 5. The activities of the compounds identified in the active extracts are also reported in Table 6. 


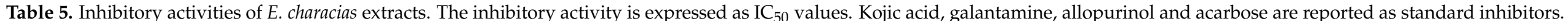
The mode of inhibition, when known, is shown in square brackets.

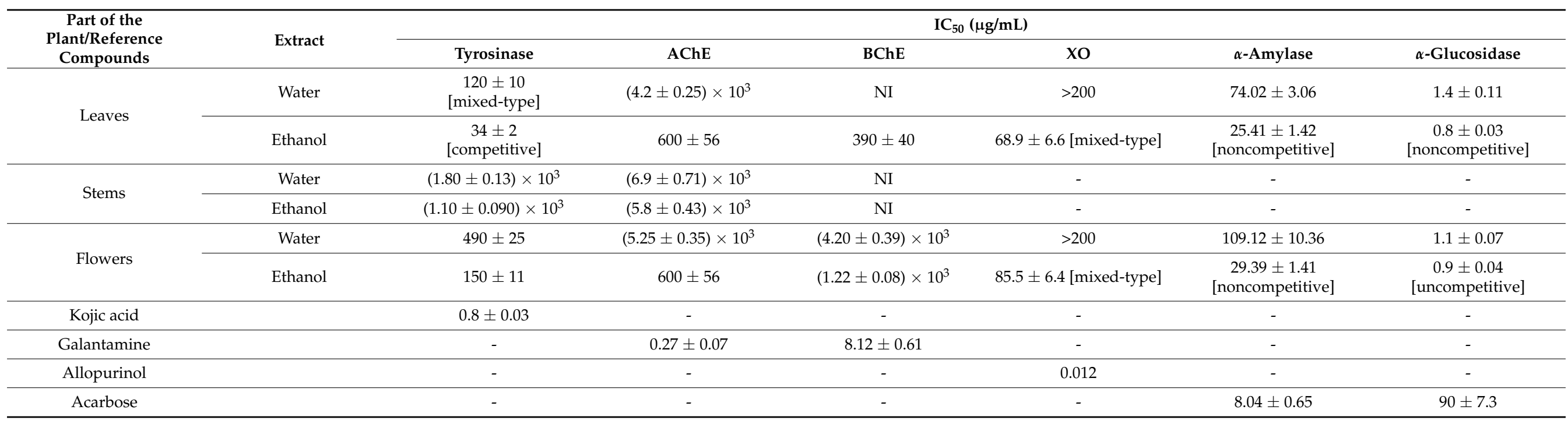

NI: no inhibition. 
Table 6. Compounds identified in E. characias flower and leaf ethanolic extracts with referred inhibitory activity.

\begin{tabular}{|c|c|c|c|c|c|c|}
\hline Compound & Tyrosinase & AChE & BChE & $\mathrm{XO}$ & $\alpha$-Amylase & $\alpha$-Glucosidase \\
\hline quercetin 74 & [40-42] & {$[43-46]$} & {$[43,44,46,47]$} & {$[48,49]$} & {$[50,51]$} & {$[50,52-54]$} \\
\hline quercetin-3-O-glucoside 75 & {$[41,55,56]$} & - & - & [57] & {$[58]$} & [59] \\
\hline quercetin-3-O-xyloside 76 & {$[60]$} & - & - & - & - & - \\
\hline quercetin-3-O-arabinoside $\mathbf{7 7}$ & {$[60]$} & - & - & - & - & [61] \\
\hline quercetin-3-O-rhamnoside $\mathbf{7 8}$ & [62] & [63] & - & - & - & [52] \\
\hline gallic acid $\mathbf{8 1}$ & {$[64,65]$} & [46] & [46] & {$[66]$} & NI [67] & [67] \\
\hline catechin 82 & {$[68]$} & [69] & [69] & [70] & [71] & [72] \\
\hline di-O-caffeoylquinic acid 84 & {$[73,74]$} & - & - & [75] & [76] & [77] \\
\hline kaempferol-3-O-arabinoside 88 & - & - & - & - & - & [61] \\
\hline kaempferol-3-O-rhamnoside 89 & [78] & [63] & - & - & - & [61] \\
\hline
\end{tabular}




\subsection{Anti-Aging Properties}

Tyrosinase, elastase and collagenase are some of the target enzymes in aging treatment or prevention. Tyrosinase (EC 1.14.18.1) is the key enzyme in the synthesis of melanin biopolymers. Melanin is produced in melanocytes by numerous enzymatic and nonenzymatic reactions. The first step is the conversion of tyrosine in 3,4-dihydroxyphenylalanine (L-DOPA) by a reaction of hydroxylation, followed by oxidation of L-DOPA to 0 -dopaquinone. These two reactions are catalyzed by tyrosinase and represent the rate-limiting step in melanin production. The subsequent steps involve oxidation and polymerization reactions and the action of other enzymes, such as the tyrosinase-related proteins. Melanin has an important skin photoprotective role, being able to absorb UV radiation and protect cells and tissues from the toxic effects of this radiation. However, inhibition of melanogenesis is particularly important on two fronts: cosmetics and medicine. An excess of melanin production can cause hyperpigmentation-related disorders such as melasma, age spots and freckles.

Extracts from E. characias aerial parts showed antimelanogenic properties. Among them, leaves ethanolic extracts showed the best activities (Table 5). Mushroom tyrosinase activity was inhibited with an $\mathrm{IC}_{50}$ of $34 \mu \mathrm{g} / \mathrm{mL}$. The extract also showed antimelanogenic activity, inhibiting cellular tyrosinase activity by $47 \%$ and $57 \%$ at 50 and $100 \mu \mathrm{g} / \mathrm{mL}$, respectively, using the B16F10 cellular model. A stronger effect than the standard compound, kojic acid, was determined [79]. As reported in Table 6, some of the compounds identified in flower and leaf ethanolic extracts of E. characias exhibited a well-documented inhibitory activity toward tyrosinase.

Quercitrin and two other quercetin derivatives were isolated from the methanolic extract of aerial parts of E. characias subsp. wulfenii, and these compounds were found to significantly inhibit elastase and collagenase activities [33]. Inhibition of these enzymes is linked with a wound-healing effect (see the next section "In vivo wound-healing activity") and skin-aging prevention. Elastase (EC 3.4.21.36) and collagenase (EC3.4.24.3) are indeed enzymes that degrade the proteins elastin and collagen, involved in the elasticity and structure of the extracellular matrix. Thus, inhibition of these enzymes contributes to the prevention of wrinkle formation, characteristic of the skin-aging process.

\subsection{In Vivo Wound-Healing Activity}

In traditional medicine, E. characias latex and aerial parts are used to treat wounds. Significant wound-healing activity was reported from extracts of E. characias subsp. wulfenii. Active constituents were identified in methanolic extracts: quercetin-3-O-rhamnoside, quercetin-3-O-galactoside and quercetin-3-O-arabinoside. These compounds were present in extracts of the aerial parts of plant in different concentrations. These three phytoconstituents could be responsible for the wound-healing potential of the plant extract. Quercetin-3-O-rhamnoside was shown to be the most abundant compound in this extract of E. characias subsp. wulfenii [33]. Quercetin-3-O-rhamnoside and quercetin-3-O-arabinoside were also identified in alcoholic extracts of the leaves and stems of $E$. characias subsp. characias. In all extracts, quercetin-3-O-rhamnoside was the most abundant compound [25,31]. Bacterial infections or an over-production of reactive oxygen species (ROS) can reduce the process of wound healing. This process may be improved using antioxidant and antibacterial agents. The alcoholic extracts, fractions and isolated compounds from aerial parts of E. characias exhibited antimicrobial and antioxidant activities. Furthermore, the aerial parts of E. characias subsp. wulfenii possess anti-inflammatory activities [31,33]. Tsatsop Tsague et al. (2020) [80] reported the antioxidant and antimicrobial activities of quercetin-3$O$-rhamnoside, one of the main compounds identified in aerial parts of $E$. characias species. Furthermore, quercetin-3-O-arabinoside was described to have antibacterial activity against Bacillus cereus and Salmonella enteritidis [81].

The quercetin glycosides mentioned above also showed collagenase and elastase enzyme inhibitory activity. In wound repair, collagenase and elastase activity catalyze the turn-over and restructuring of matrix components, which is a significant event in 
wound repair. These quercetin glycosides, with their activities, could contribute to the wound-healing activity shown by the extracts of the plant. All of this evidence supports the ethnomedicine use of the aerial parts of E. characias in folk medicine.

\subsection{Cholinesterases Inhibition}

Acetylcholinesterase (AChE, EC 3.1.1.7) and butyrylcholinesterase (BChE, EC 3.1.1.8) are enzymes associated with the pathology of Alzheimer's disease (AD). In fact, one of the main causes linked to the onset of $\mathrm{AD}$ is the lack of acetylcholine. This neurotransmitter is hydrolyzed by both $\mathrm{AChE}$ and $\mathrm{BChE}$, whose activities are enhanced in $\mathrm{AD}$ condition. Thus, the inhibition of these enzymes, enhancing the level of the neurotransmitter acetylcholine, represent one of the strategies in $\mathrm{AD}$ treatment.

Latex and aerial part extracts of E. characias were tested for their cholinesterase inhibition. Leaves, stems and flowers were extracted with water and ethanol and, as seen also from other enzyme inhibitions, the alcoholic extracts showed the best activity. The best result was obtained with leaves ethanolic extract on both cholinesterases, but it was more effective against $\mathrm{BChE}$, even if the $\mathrm{IC}_{50}$ value was higher than the reference compound galantamine (Table 5). Latex extracted with trichloroacetic acid was tested only against $\mathrm{AChE}$ and showed good inhibition [30]. Analysis of latex composition showed the presence of several acid and phenolic compounds. Some of these compounds are reported to be AChE inhibitors, such as compounds 57 and 60-64 [82-84].

Table 6 reports some of the compounds identified in flower and leaf ethanolic extracts of $E$. characias, showing documented inhibitory activity against cholinesterase enzymes. The most present compounds in those extracts are the derivatives of quercetin and, among them, only the quercetin rhamnoside shows inhibitory activity against AChE (Table 6).

\subsection{Xanthine Oxidase Inhibition}

The purine metabolism in humans leads to the formation of uric acid. This final product, excreted in urine, is formed by the oxidation catalyzed by Xanthine oxidase (XO, EC 1.2.3.2) of hypoxanthine and xanthine, with concomitant production of ROS. The accumulation of uric acid results from an overproduction, due to an increased purine ingestion and metabolization, or from a decrease in its urinary excretion. Crystals of uric acid deposit in the joints, mostly in knee, elbow and ankle, causing severe pain and inflammation, and are responsible for the pathogenesis of gout. In order to control uric acid deposition, $\mathrm{XO}$ has been used as a therapeutic target, and its inhibitors are therefore used in the treatment of hyperuricemia and gout. Since XO is also a pro-oxidant enzyme, inhibitors with antioxidant activities are of much interest.

Inhibitory activity of leaves and flowers of E. characias was reported [32]. Only ethanolic extracts showed enzyme inhibition, which was higher than the standard inhibitor allopurinol (Table 5). Some of the compounds identified in flower and leaf ethanolic extracts of E. characias with a referred inhibitory activity against $\mathrm{XO}$ are reported in Table 6 .

\subsection{Hypoglycemic Properties}

Hyperglycemia is a condition of an excessive amount of glucose in the blood serum, which may be associated with diabetes and related cardiovascular diseases. It requires emergency treatment. One of the main therapeutic strategies to treat diabetes is to decrease postprandial hyperglycemia by the inhibition of carbohydrate hydrolyzing enzymes, such as $\alpha$-amylase and $\alpha$-glucosidase. These enzymes break down complex carbohydrates and disaccharides to glucose, which is absorbed in the bloodstream. $\alpha$-amylase (EC 3.2.1.1) is a key enzyme that catalyzes the endo-hydrolysis of $\alpha$-D- $(1,4)$ glycosidic linkages in dietary starch, glycogen and carbohydrates with three or more glucose units. The oligosaccharides produced by $\alpha$-amylase reaction are then degraded to free D-glucose by $\alpha$-glucosidase (EC 3.2.1.3) in the small intestine. Thus, inhibition of these enzymes can suppress carbohydrate digestion, reduce glucose uptake and consequently, it may be helpful to reduce the postprandial glucose levels. Several enzyme inhibitors have been 
approved as antidiabetic drugs, such as acarbose and miglitol, but they induce side effects, and the identification of novel potential inhibitors is of great interest. Presently, only aerial parts of E. characias were tested for these activities and the results are encouraging for further investigation [32]. Both the enzymes are inhibited by plant extracts, but the best effect is showed against $\alpha$-glucosidase. The $\alpha$-glucosidase inhibitory activity of the ethanolic extracts was therefore found to be about 100 times higher than the standard compound acarbose (Table 6). Kinetic analysis showed that both extracts from leaves and flowers act as noncompetitive inhibitors against $\alpha$-amylase, while mode of inhibition on $\alpha$-glucosidase revealed that leaves and flowers act as noncompetitive and uncompetitive inhibitors, respectively. Moreover, it is noteworthy that the therapeutic drugs usually used for the treatment of hyperglycemia in diabetic patients, such as acarbose, show side effects probably correlated with a more significant inhibition of a-amylase if compared to $\alpha$-glucosidase inhibition [85]. Leaf and flower ethanolic extracts showed a ratio between $\alpha$-amylase and $\alpha$-glucosidase inhibition higher than the ratio of acarbose, marking these extracts as good candidates for further study.

Table 6 reports the compounds identified in flower and leaf ethanolic extracts of E. characias showing documented inhibitory activity against $\alpha$-amylase and $\alpha$-glucosidase.

\subsection{Antioxidant Activity}

The biological activities highlighted for Euphorbia species included antioxidant activity. In these species, there is a vast number of different types of antioxidant compounds that could have a key role in preventing free radical chain reactions. Free radicals cause grave cell and tissue damage, which is the main cause of the aging process and the pathogenesis of several diseases.

The analysis of TCA extract of E. characias latex has highlighted high antioxidant activity; a higher amount of antioxidants was detected using $\mathrm{ABTS}^{+}{ }^{\bullet}$ instead of $\mathrm{DPPH}^{\bullet}$ assay [30]. Pintus et al. (2010) [4] reported, in E. characias latex, the presence of proteins that act as antioxidant enzymes. The antioxidant molecules and enzymatic proteins could act contemporarily as mechanisms of defense in the plant [30]. The activities of aqueous and alcoholic extracts from aerial parts of E. characias were evaluated with different assays. Leaf ethanolic extract exhibited significantly higher free radical scavenging activity if compared with aqueous extracts [31]. Moreover, leaf and flower ethanolic extracts showed no cytotoxic activity and inhibited $\mathrm{H}_{2} \mathrm{O}_{2}$-induced ROS generation in a cellular system [32]. Several compounds identified in E. characias are well-known antioxidant molecules [86-107] which could be responsible for the activity detected in the extracts.

\subsection{Antiviral, Antimicrobial and Pesticidal Activities}

The demand for bioactive compounds from natural sources is continuously increasing, because antibiotics and their extensive use led to the emergent problem of the multidrug resistance of microorganisms related to antibiotics and their extensive use. Several studies reported plant antimicrobials efficacy towards a great number of pathogens and foodborne agents that can cause viral infections and several diseases. In this context, aqueous and alcoholic extracts from aerial parts of $E$. characias have been investigated for their antiviral and antimicrobial efficacy. With regard to the antiviral effect, activities against the human immunodeficiency virus type 1 (HIV-1) reverse transcriptase-(RT-) associated RNA-dependent DNA polymerase (RDDP) and Ribonuclease H (RNase H) were evaluated. These activities are crucial for viral replication, and therefore they represent important drug targets for which there is a need for new drugs. All the extracts possessed anti-HIV activity and among them, ethanolic extracts were more active than aqueous extracts, and the ethanolic extract from flowers seemed to be the most effective inhibitor of HIV-1 RTassociated RNA-dependent DNA polymerase and Ribonuclease $\mathrm{H}$. Among the compounds identified in flower and leaf ethanolic extracts of E. characias, compounds 74, 78, 81, 84 and 89 showed documented HIV inhibitory activity [108-111]. 
Moreover, E. characias extracts were tested in order to evaluate an antagonistic activity against a panel of microorganisms: Staphylococcus aureus, Bacillus cereus, Listeria monocytogenes, Escherichia coli, Salmonella typhimurium, Candida albicans, Saccharomyces cerevisiae, Aspergillus flavus and Penicillium chrysogenum. Extracts from leaves appeared to possess the best antibacterial activity, followed by flower and stem extracts. Ethanolic extracts from leaves displayed the highest antibacterial activity towards all the tested Gram-positive bacteria: B. cereus, L. monocytogenes and S. aureus [31]. Among the compounds identified in this extract, antibacterial activity versus $S$. aureus was reported for compounds 75, 77, 81, 82 and 84 [112-116]. Activity against L. monocytogenes and B. cereus was reported for compounds 77, 81 and 82 [113,115,117] and 75 and 81 [112,114], respectively.

In addition to these properties, the antifungal activity of crude latex extract was reported [118]. The antifungal effect of plant latex seems to be related to the action of lysosomal hydrolases. These enzymes can be responsible for cell wall degradation, which results in a better entrance of antifungal drugs from extracellular medium. The concomitant use of latex and antifungal drugs may reduce the dose of drugs in the treatment of mycoses, therefore decreasing their side effects. E. characias latex showed an antifungal effect, alone and in combination with the synthetic imidazole drug, ketoconazole [118].

Plant chitinases exert a significant role in plant defense, acting on chitin-containing pathogens, and they also show antimicrobial, antiviral and insecticidal properties. In recent years, a chitinase was identified and purified from E. characias latex (ELC) [9]. ELC proved to be an effective management strategy against the insect Drosophila suzukii, which has recently caused important economic losses in Europe due to their attacks on developing soft fruits, by degrading the chitin exoskeleton of D. suzukii. Moreover, ELC at concentrations that were harmless to the host plants could be considered an environmentally friendly alternative to chemical pesticides, opening the door to develop sustainable agriculture [119].

\section{Conclusions}

Plant products are still major sources of innovative therapeutic agents, and since ancient times they have been widely used to treat many diseases, such as cancer, diabetes and cardiovascular and neurodegenerative diseases. Bioactive compounds from natural sources, as an alternative to synthetic molecules, are increasingly in demand, since they provide unlimited opportunities for new drug discoveries because of the unmatched availability of chemical diversity. In addition to the identification of new molecules with biological properties, there is growing evidence that known molecules are finding new applications through better understanding of molecular biology and clinical observations.

E. characias, cited in most ancient treatises of Greek and Latin medicine, is one of the oldest known medicinal plants of the Western tradition. The different phytochemicals, produced in the latex, seeds, steams, leaves and flowers of this plant, are terpenoids, sterol hydrocarbons, fatty acids, cerebrosides and phenolic and carboxylic acid compounds. In addition to these compounds, E. characias latex contains a low-molecular-weight natural rubber.

The E. characias biological properties reported in this review allow us to consider its wide potential therapeutic application. Indeed, it represents a source of inhibitors of target enzymes related to different oxidative stress-related diseases such as diabetes, Alzheimer's and hyperpigmentation disorders, as well as microbial and viral infections. Once the bioactive compounds are identified, future prospects include further studies through in vitro and in vivo approaches in order to develop new, effective drugs. Moreover, vehiculation of active compounds represents an emerging technology and could be used to improve the delivery and efficacy of these compounds.

Although the plant $E$. characias needs additional physicochemical and chemical analyses, and a majority of its phytochemicals require further in-depth characterization for their therapeutic efficacy and safety, we believe that this review may contribute to provide the scientific basis for future study and full use of this plant. 
Author Contributions: Conceptualization, A.F., G.L.D., F.P. and R.M.; writing-original draft preparation, A.F, G.L.D., S.F., B.E., F.P. and R.M.; writing-review and editing, A.F, G.L.D., F.P. and R.M. All authors have read and agreed to the published version of the manuscript.

Funding: This research received no external funding.

Data Availability Statement: Data is contained within the article.

Conflicts of Interest: The authors declare no conflict of interest.

\section{References}

1. Kemboi, D.; Peter, X.; Langat, M.; Tembu, J. A review of the ethnomedicinal uses, biological activities, and triterpenoids of euphorbia species. Molecules 2020, 25, 4019. [CrossRef]

2. Mwine, J.T.; van Damme, P. Why do euphorbiaceae tick as medicinal plants? A review of euphorbiaceae family and its medicinal features. J. Med. Plants Res. 2011, 5, 652-662.

3. Salehi, B.; Iriti, M.; Vitalini, S.; Antolak, H. Euphorbia-derived natural products with potential for use in health maintenance. Biomolecules 2019, 9, 337. [CrossRef] [PubMed]

4. Pintus, F.; Medda, R.; Rinaldi, A.C.; Spanò, D.; Floris, G. Euphorbia latex biochemistry: Complex interactions in a complex environment. Plant Biosyst. 2010, 144, 381-391. [CrossRef]

5. Pintus, F.; Spanò, D.; Medda, R.; Floris, G. Calcium ions and a secreted peroxidase in Euphorbia characias latex are made for each other. Protein J. 2011, 30, 115-123. [CrossRef] [PubMed]

6. Pintus, F.; Sabatucci, A.; Maccarrone, M.; Dainese, E.; Medda, R. Amine oxidase from Euphorbia characias: Kinetic and structural characterization. Biotechnol. Appl. Biochem. 2018, 65, 81-88. [CrossRef]

7. Pintus, F.; Spano, D.; Corongiu, S.; Floris, G.; Medda, R. Purification, primary structure, and properties of Euphorbia characias latex purple acid phosphatase. Biochemistry 2011, 76, 694-701. [CrossRef]

8. Sabatucci, A.; Pintus, F.; Cabras, T.; Vincenzoni, F.; Maccarrone, M.; Medda, R.; Dainese, E. Structure of a nucleotide pyrophosphatase/phosphodiesterase (NPP) from Euphorbia characias latex characterized by small-angle X-ray scattering: Clues for the general organization of plant NPPs. Acta Crystallogr. Sect. D Struct. Biol. 2020, 76, 857-867. [CrossRef]

9. Spanò, D.; Pospiskova, K.; Safarik, I.; Pisano, M.B.; Pintus, F.; Floris, G.; Medda, R. Chitinase III in Euphorbia characias latex: Purification and characterization. Protein Expr. Purif. 2015, 116, 152-158. [CrossRef] [PubMed]

10. Tholl, D. Biosynthesis and biological functions of terpenoids in plants. Adv. Biochem. Eng. Biotechnol. 2015, 148, 63-106. [CrossRef]

11. Shi, Q.W.; Su, X.H.; Kiyota, H. Chemical and pharmacological research of the plants in genus Euphorbia. Chem. Rev. 2008, 108, 4295-4327. [CrossRef]

12. Appendino, G.; Belloro, E.; Cesare Tron, G.; Jakupovic, J.; Ballero, M. Polycyclic diterpenoids from Euphorbia characias. Fitoterapia 2000, 71, 134-142. [CrossRef]

13. Vasas, A.; Hohmann, J. Euphorbia diterpenes: Isolation, Structure, biological activity, and synthesis (2008-2012). Chem. Rev. 2014, 114, 8579-8612. [CrossRef] [PubMed]

14. Valente, C.; Pedro, M.; Duarte, A.; Maria, M.S.J.N.; Abreu, P.M.; Ferreira, M.J.U. Bioactive diterpenoids, a new jatrophane and two ent-abietanes, and other constituents from Euphorbia pubescens. J. Nat. Prod. 2004, 67, 902-904. [CrossRef] [PubMed]

15. Yu, C.C.; Hsieh, C.R.; Hsiao, G.; Chen, P.Y.; Chang, M.L.; Yin, H.W.; Lee, T.H.; Lee, C.K. Regulated expressions of MMP-2, -9 by diterpenoids from Euphorbia formosana hayata. Molecules 2012, 17, 2082-2090. [CrossRef]

16. Gill, S.E.; Parks, W.C. Metalloproteinases and their inhibitors: Regulators of wound healing. Int. J. Biochem. Cell Biol. 2008, 40, 1334-1347. [CrossRef]

17. Gustafson, K.R.; Munro, M.H.G.; Blunt, J.W.; Cardellina, J.H.; McMahon, J.B.; Gulakowski, R.J.; Cragg, G.M.; Cox, P.A.; Brinen, L.S.; Clardy, J.; et al. HIV inhibitory natural products. 3. Diterpenes from Homalantus acuminatus and Chrysobalanus icaco. Tetrahedron 1991, 47, 4547-4554. [CrossRef]

18. Christodoulakis, N.S.; Mamoucha, S.; Termentzi, A.; Fokialakis, N. Leaf structure and histochemistry of the hardy evergreen Euphorbia characias L. (Mediterranean spurge). Flora Morphol. Distrib. Funct. Ecol. Plants 2015, 210, 13-18. [CrossRef]

19. Seip, E.H.; Hecker, E. Lathyrane type diterpenoid esters from Euphorbia characias. Phytochemistry 1983, 22, 1791-1795. [CrossRef]

20. Seip, E.H.; Hecker, E. Derivatives of characiol, macrocyclic diterpene esters of the jatrophane type from Euphorbia characias. Phytochemistry 1984, 23, 1689-1694. [CrossRef]

21. Corea, G.; Fattorusso, E.; Lanzotti, V.; Motti, R.; Simon, P.N.; Dumontet, C.; Di Pietro, A. Structure-activity relationships for euphocharacins A-L, a new series of jatrophane diterpenes, as inhibitors of cancer cell P-glycoprotein. Planta Med. 2004, 70, 657-665. [CrossRef] [PubMed]

22. Barile, E.; Corea, G.; Lanzotti, V. Diterpenes from Euphorbia as potential leads for drug design. Nat. Prod. Commun. 2008, 3, 1003-1020. [CrossRef]

23. Carriere, F.; Chagvardieff, P.; Gil, G.; Pean, M.; Sigoillot, J.C.; Tapie, P. Fatty acid patterns of neutral lipids from seeds, leaves and cell suspension cultures of Euphorbia characias. Phytochemistry 1992, 31, 2351-2353. [CrossRef]

24. Bruni, R.; Muzzoli, M.; Ballero, M.; Loi, M.C.; Fantin, G.; Poli, F.; Sacchetti, G. Tocopherols, fatty acids and sterols in seeds of four Sardinian wild Euphorbia species. Fitoterapia 2004, 75, 50-61. [CrossRef] 
25. Escrig, P.V.; Iglesias, D.J.; Corma, A.; Primo, J.; Primo-Millo, E.; Cabedo, N. Euphorbia characias as bioenergy crop: A study of variations in energy value components according to phenology and water status. J. Agric. Food Chem. 2013, 61, 10096-10109. [CrossRef] [PubMed]

26. Boieiro, M.; Espadaler, X.; Gómez, C.; Eustaquio, A. Spatial variation in the fatty acid composition of elaiosomes in an antdispersed plant: Differences within and between individuals and populations. Flora Morphol. Distrib. Funct. Ecol. Plants 2012, 207, 497-502. [CrossRef]

27. Palomino-Schätzlein, M.; Escrig, P.V.; Boira, H.; Primo, J.; Pineda-Lucena, A.; Cabedo, N. Evaluation of nonpolar metabolites in plant extracts by 13C NMR spectroscopy. J. Agric. Food Chem. 2011, 59, 11407-11416. [CrossRef]

28. Falsone, G.; Cateni, F.; Katusian, F.; Wagner, H.; Seligmann, O.; Pellizer, G.; Asaro, F. New cerebrosides from Euphorbia characias Z. Fur. Naturforsch. Sect. B J. Chem. Sci. 1993, 48, 1121-1126. [CrossRef]

29. Falsone, G.; Cateni, F.; Baumgartner, M.; Lucchini, V.; Wagner, H.; Seligmann, O. Isolation and structure elucidation of five cerebrosides from Euphorbia characias L. Z. Fur. Naturforsch. Sect. B J. Chem. Sci. 1994, 49, 135-140. [CrossRef]

30. Pintus, F.; Spanò, D.; Mascia, C.; Macone, A.; Floris, G.; Medda, R. Acetylcholinesterase inhibitory and antioxidant properties of Euphorbia characias latex. Rec. Nat. Prod. 2013, 7, 147-151.

31. Pisano, M.B.; Cosentino, S.; Viale, S.; Spanò, D.; Corona, A.; Esposito, F.; Tramontano, E.; Montoro, P.; Tuberoso, C.I.G.; Medda, R.; et al. Biological activities of aerial parts extracts of Euphorbia characias. Biomed. Res. Int. 2016, 2016. [CrossRef]

32. Fais, A.; Era, B.; Di Petrillo, A.; Floris, S.; Piano, D.; Montoro, P.; Tuberoso, C.I.G.; Medda, R.; Pintus, F. Selected enzyme inhibitory effects of Euphorbia characias extracts. Biomed. Res. Int. 2018, 2018. [CrossRef]

33. Özbilgin, S.; Acıkara, Ö.B.; Akkol, E.K.; Süntar, I.; Keleş, H.; İşcan, G.S. In vivo wound-healing activity of Euphorbia characias subsp. Wulfenii: Isolation and quantification of quercetin glycosides as bioactive compounds. J. Ethnopharmacol. 2018, 224, 400-408. [CrossRef] [PubMed]

34. Fokialakis, N.; Melliou, E.; Magiatis, P.; Harvala, C.; Mitaku, S. Composition of the steam volatiles of six Euphorbia spp. from Greece. Flavour Fragr. J. 2003, 18, 39-42. [CrossRef]

35. Cornish, K.; Blakeslee, J. Rubber Biosynthesis in Plants. Available online: https://lipidlibrary.aocs.org/chemistry/physics/plantlipid/rubber-biosynthesis-in-plants (accessed on 15 July 2021).

36. Cherian, S.; Ryu, S.B.; Cornish, K. Natural rubber biosynthesis in plants, the rubber transferase complex, and metabolic engineering progress and prospects. Plant Biotechnol. J. 2019, 17, 2041-2061. [CrossRef]

37. Spanò, D.; Pintus, F.; Mascia, C.; Scorciapino, M.A.; Casu, M.; Floris, G.; Medda, R. Extraction and characterization of a natural rubber from Euphorbia characias latex. Biopolymers 2012, 97, 589-594. [CrossRef]

38. Mekkriengkrai, D.; Ute, K.; Swiezewska, E.; Chojnacki, T.; Tanaka, Y.; Sakdapipanich, J.T. Structural characterization of rubber from Jackfruit and Euphorbia as a model of natural rubber. Biomacromolecules 2004, 5, 2013-2019. [CrossRef] [PubMed]

39. Spanò, D.; Pintus, F.; Esposito, F.; Loche, D.; Floris, G.; Medda, R. Euphorbia characias latex: Micromorphology of rubber particles and rubber transferase activity. Plant Physiol. Biochem. 2015, 87, 26-34. [CrossRef]

40. Chen, Q.X.; Kubo, I. Kinetics of mushroom tyrosinase inhibition by quercetin. J. Agric. Food Chem. 2002, 50, 4108-4112. [CrossRef] [PubMed]

41. Xue, Y.L.; Miyakawa, T.; Hayashi, Y.; Okamoto, K.; Hu, F.; Mitani, N.; Furihata, K.; Sawano, Y.; Tanokura, M. Isolation and tyrosinase inhibitory effects of polyphenols from the leaves of persimmon, Diospyros kaki. J. Agric. Food Chem. 2011, 59, 6011-6017. [CrossRef] [PubMed]

42. Fan, M.; Zhang, G.; Hu, X.; Xu, X.; Gong, D. Quercetin as a tyrosinase inhibitor: Inhibitory activity, conformational change and mechanism. Food Res. Int. 2017, 100, 226-233. [CrossRef] [PubMed]

43. Ademosun, A.O.; Oboh, G.; Bello, F.; Ayeni, P.O. Antioxidative properties and effect of quercetin and its glycosylated form (rutin) on acetylcholinesterase and butyrylcholinesterase activities. J. Evid. Based Complement. Altern. Med. 2016, 21, NP11-NP17. [CrossRef]

44. Khan, M.T.H.; Orhan, I.; Şenol, F.S.; Kartal, M.; Şener, B.; Dvorská, M.; Šmejkal, K.; Šlapetová, T. Cholinesterase inhibitory activities of some flavonoid derivatives and chosen xanthone and their molecular docking studies. Chem. Biol. Interact. 2009, 181, 383-389. [CrossRef] [PubMed]

45. Jung, M.; Park, M. Acetylcholinesterase inhibition by flavonoids from Agrimonia pilosa. Molecules 2007, 12, 2130-2139. [CrossRef]

46. Orhan, I.; Kartal, M.; Tosun, F.; Şener, B. Screening of various phenolic acids and flavonoid derivatives for their anticholinesterase potential. Z. Fur. Naturforsch. Sect. C J. Biosci. 2007, 62, 829-832. [CrossRef] [PubMed]

47. Katalinić, M.; Bosak, A.; Kovarik, Z. Flavonoids as inhibitors of human butyrylcholinesterase variants. Food Technol. Biotechnol. 2014, 52, 64-67.

48. Webster, G.L. Irritant plants in the spurge family (Euphorbiaceae). Clin. Dermatol. 1986, 4, 36-45. [CrossRef]

49. Zhang, C.; Wang, R.; Zhang, G.; Gong, D. Mechanistic insights into the inhibition of quercetin on xanthine oxidase. Int. J. Biol. Macromol. 2018, 112, 405-412. [CrossRef] [PubMed]

50. Oboh, G.; Ademosun, A.O.; Ayeni, P.O.; Omojokun, O.S.; Bello, F. Comparative effect of quercetin and rutin on $\alpha$-amylase, $\alpha$-glucosidase, and some pro-oxidant-induced lipid peroxidation in rat pancreas. Comp. Clin. Path. 2015, 24, 1103-1110. [CrossRef]

51. Yuan, E.; Liu, B.; Wei, Q.; Yang, J.; Chen, L.; Li, Q. Structure activity relationships of flavonoids as potent $\alpha$-amylase inhibitors. Nat. Prod. Commun. 2014, 9, 1173-1176. [CrossRef] 
52. Utari, F.; Itam, A.; Syafrizayanti, S.; Putri, W.H.; Ninomiya, M.; Koketsu, M.; Tanaka, K.; Efdi, M. Isolation of flavonol rhamnosides from Pometia pinnata leaves and investigation of $\alpha$-glucosidase inhibitory activity of flavonol derivatives. J. Appl. Pharm. Sci. 2019, 9, 53-65. [CrossRef]

53. Proença, C.; Freitas, M.; Ribeiro, D.; Oliveira, E.F.T.; Sousa, J.L.C.; Tomé, S.M.; Ramos, M.J.; Silva, A.M.S.; Fernandes, P.A.; Fernandes, E. $\alpha$-Glucosidase inhibition by flavonoids: An in vitro and in silico structure-activity relationship study. J. Enzyme Inhib. Med. Chem. 2017, 32, 1216-1228. [CrossRef] [PubMed]

54. Wan-Nadilah, W.A.; Akhtar, M.T.; Shaari, K.; Khatib, A.; Hamid, A.A.; Hamid, M. Variation in the metabolites and $\alpha$-glucosidase inhibitory activity of Cosmos caudatus at different growth stages. BMC Complement. Altern. Med. 2019, 19, 245. [CrossRef]

55. Arung, E.T.; Furuta, S.; Ishikawa, H.; Kusuma, I.W.; Shimizu, K.; Kondo, R. Anti-melanogenesis properties of quercetin- and its derivative-rich extract from Allium cepa. Food Chem. 2011, 124, 1024-1028. [CrossRef]

56. Bhullar, K.S.Z.; Warnakulasuriya, S.N.; Rupasinghe, H.P.V. Biocatalytic synthesis, structural elucidation, antioxidant capacity and tyrosinase inhibition activity of long chain fatty acid acylated derivatives of phloridzin and isoquercitrin. Bioorganic Med. Chem. 2013, 21, 684-692. [CrossRef]

57. Mehmood, A.; Ishaq, M.; Zhao, L.; Safdar, B.; Rehman, A.; Munir, M.; Raza, A.; Nadeem, M.; Iqbal, W.; Wang, C. Natural compounds with xanthine oxidase inhibitory activity: A review. Chem. Biol. Drug Des. 2019, 93, 387-418. [CrossRef] [PubMed]

58. Liao, L.; Chen, J.; Liu, L.; Xiao, A. Screening and binding analysis of flavonoids with alpha-amylase inhibitory activity from lotus leaf. J. Braz. Chem. Soc. 2018, 29, 587-593. [CrossRef]

59. Li, Y.Q.; Zhou, F.C.; Gao, F.; Bian, J.S.; Shan, F. Comparative evaluation of quercetin, isoquercetin and rutin as inhibitors of $\alpha$-glucosidase. J. Agric. Food Chem. 2009, 57, 11463-11468. [CrossRef]

60. Aoyama, H.; Sakagami, H.; Hatano, T. Three new flavonoids, proanthocyanidin, and accompanying phenolic constituents from Feijoa sellowiana. Biosci. Biotechnol. Biochem. 2018, 82, 31-40. [CrossRef]

61. Xu, R.; Bu, Y.G.; Zhao, M.L.; Tao, R.; Luo, J.; Li, Y. Studies on antioxidant and $\alpha$-glucosidase inhibitory constituents of Chinese toon bud (Toona sinensis). J. Funct. Foods 2020, 73. [CrossRef]

62. Jeong, C.H.; Shim, K.H. Tyrosinase inhibitor isolated from the leaves of Zanthoxylum piperitum. Biosci. Biotechnol. Biochem. 2004, 68, 1984-1987. [CrossRef]

63. Aderogba, M.A.; Ndhlala, A.R.; Rengasamy, K.R.R.; Van Staden, J. Antimicrobial and selected in vitro enzyme inhibitory effects of leaf extracts, flavonols and indole alkaloids isolated from Croton menyharthii. Molecules 2013, 18, 12633-12644. [CrossRef]

64. Nithitanakool, S.; Pithayanukul, P.; Bavovada, R.; Saparpakorn, P. Molecular docking studies and anti-tyrosinase activity of thai mango seed kernel extract. Molecules 2009, 14, 257-265. [CrossRef]

65. Kim, Y.J. Antimelanogenic and antioxidant properties of gallic acid. Biol. Pharm. Bull. 2007, 30, 1052-1055. [CrossRef] [PubMed]

66. Choudhary, D.K.; Mishra, A. In vitro and in silico interaction of faba bean (Vicia faba L.) seed extract with xanthine oxidase and evaluation of antioxidant activity as a therapeutic potential. Nat. Prod. Res. 2019, 33, 2689-2693. [CrossRef] [PubMed]

67. Kam, A.; Li, K.M.; Razmovski-Naumovski, V.; Nammi, S.; Shi, J.; Chan, K.; Li, G.Q. A comparative study on the inhibitory effects of different parts and chemical constituents of pomegranate on $\alpha$-amylase and $\alpha$-glucosidase. Phyther. Res. 2013, 27, 1614-1620. [CrossRef]

68. Tang, H.; Cui, F.; Li, H.; Huang, Q.; Li, Y. Understanding the inhibitory mechanism of tea polyphenols against tyrosinase using fluorescence spectroscopy, cyclic voltammetry, oximetry, and molecular simulations. RSC Adv. 2018, 8, 8310-8318. [CrossRef]

69. Suganthy, N.; Pandima Devi, K. In vitro antioxidant and anti-cholinesterase activities of Rhizophora mucronata. Pharm. Biol. 2016, 54, 118-129. [CrossRef] [PubMed]

70. Nagao, A.; Seki, M.; Kobayashi, H. Inhibition of xanthine oxidase of flavonoids. Biosci. Biotechnol. Biochem. 1999, 63, 1787-1790. [CrossRef]

71. Júnior, J.P.L.; de Franco, R.R.; Saraiva, A.L.; Moraes, I.B.; Espindola, F.S. Anacardium humile St. Hil as a novel source of antioxidant, antiglycation and $\alpha$-amylase inhibitors molecules with potential for management of oxidative stress and diabetes. J. Ethnopharmacol. 2021, 268. [CrossRef]

72. Zhao, L.; Wen, L.; Lu, Q.; Liu, R. Interaction mechanism between $\alpha$-glucosidase and A-type trimer procyanidin revealed by integrated spectroscopic analysis techniques. Int. J. Biol. Macromol. 2020, 143, 173-180. [CrossRef] [PubMed]

73. Wang, Z.; Hwang, S.H.; Huang, B.; Lim, S.S. Identification of tyrosinase specific inhibitors from Xanthium strumarium fruit extract using ultrafiltration-high performance liquid chromatography. J. Chromatogr. B Anal. Technol. Biomed. Life Sci. 2015, 1002, 319-328. [CrossRef]

74. Strzępek-Gomółka, M.; Gaweł-Bęben, K.; Angelis, A.; Antosiewicz, B.; Sakipova, Z.; Kozhanova, K.; Głowniak, K.; Kukula-Koch, W. Identification of mushroom and murine tyrosinase inhibitors from achillea biebersteinii Afan. Extract. Molecules 2021, 26, 964. [CrossRef] [PubMed]

75. Nguyen, M.T.T.; Awale, S.; Tezuka, Y.; Le Tran, Q.; Watanabe, H.; Kadota, S. Xanthine oxidase inhibitory activity of vietnamese medicinal plants. Biol. Pharm. Bull. 2004, 27, 1414-1421. [CrossRef]

76. Olennikov, D.N.; Kashchenko, N.I. Componential profile and amylase inhibiting activity of phenolic compounds from Calendula officinalis L. leaves. Sci. World J. 2014, 2014. [CrossRef]

77. Ooi, K.L.; Muhammad, T.S.T.; Tan, M.L.; Sulaiman, S.F. Cytotoxic, apoptotic and anti- $\alpha$-glucosidase activities of 3,4-di-O-caffeoyl quinic acid, an antioxidant isolated from the polyphenolic-rich extract of Elephantopus mollis Kunth. J. Ethnopharmacol. 2011, 135, 685-695. [CrossRef] 
78. Park, S.; Jegal, J.; Chung, K.W.; Jung, H.J.; Noh, S.G.; Chung, H.Y.; Ahn, J.; Kim, J.; Yang, M.H. Isolation of tyrosinase and melanogenesis inhibitory flavonoids from Juniperus chinensis fruits. Biosci. Biotechnol. Biochem. 2018, 82, 2041-2048. [CrossRef] [PubMed]

79. Pintus, F.; Spanò, D.; Corona, A.; Medda, R. Antityrosinase activity of Euphorbia characias extracts. PeerJ 2015, 2015. [CrossRef]

80. Tsatsop Tsague, R.K.T.; Kenmogne, S.B.; Tchienou, G.E.D.; Parra, K.; Ngassoum, M.B. Sequential extraction of quercetin-3-Orhamnoside from Piliostigma thonningii Schum. leaves using microwave technology. SN Appl. Sci. 2020, 2, 1230. [CrossRef]

81. Arima, H.; Danno, G.I. Isolation of antimicrobial compounds from guava (psidium guajava L.) and their structural elucidation. Biosci. Biotechnol. Biochem. 2002, 66, 1727-1730. [CrossRef] [PubMed]

82. Jabir, N.R.; Khan, F.R.; Tabrez, S. Cholinesterase targeting by polyphenols: A therapeutic approach for the treatment of alzheimer's disease. CNS Neurosci. Ther. 2018, 24, 753-762. [CrossRef]

83. Szwajgier, D.; Borowiec, K. Phenolic acids from malt are efficient acetylcholinesterase and butyrylcholinesterase inhibitors. J. Inst. Brew. 2012, 118, 40-48. [CrossRef]

84. Dizdar, M.; Vidic, D.; Požgan, F.; Štefane, B.; Maksimović, M. Acetylcholinesterase inhibition and antioxidant activity of N-trans-caffeoyldopamine and N-trans-feruloyldopamine. Sci. Pharm. 2018, 86, 11. [CrossRef] [PubMed]

85. Oboh, G.; Ogunsuyi, O.B.; Ogunbadejo, M.D.; Adefegha, S.A. Influence of gallic acid on $\alpha$-amylase and $\alpha$-glucosidase inhibitory properties of acarbose. J. Food Drug Anal. 2016, 24, 627-634. [CrossRef] [PubMed]

86. Mathew, S.; Abraham, T.E.; Zakaria, Z.A. Reactivity of phenolic compounds towards free radicals under in vitro conditions. $J$. Food Sci. Technol. 2015, 52, 5790-5798. [CrossRef]

87. Park, H.; Kim, S.; Kim, S.; Song, Y.; Seung, K.; Hong, D.; Khang, G.; Lee, D. Antioxidant and anti-inflammatory activities of hydroxybenzyl alcohol releasing biodegradable polyoxalate nanoparticles. Biomacromolecules 2010, 11, 2103-2108. [CrossRef] [PubMed]

88. Groussard, C.; Morel, I.; Chevanne, M.; Monnier, M.; Cillard, J.; Delamarche, A. Free radical scavenging and antioxidant effects of lactate ion: An in vitro study. J. Appl. Physiol. 2000, 89, 169-175. [CrossRef]

89. Zheng, Y.Z.; Deng, G.; Liang, Q.; Chen, D.F.; Guo, R.; Lai, R.C. Antioxidant activity of quercetin and its glucosides from propolis: A theoretical study. Sci. Rep. 2017, 7, 7543. [CrossRef] [PubMed]

90. Iacopini, P.; Baldi, M.; Storchi, P.; Sebastiani, L. Catechin, epicatechin, quercetin, rutin and resveratrol in red grape: Content, in vitro antioxidant activity and interactions. J. Food Compos. Anal. 2008, 21, 589-598. [CrossRef]

91. Razavi, S.M.; Zahri, S.; Zarrini, G.; Nazemiyeh, H.; Mohammadi, S. Biological activity of quercetin-3-O-glucoside, a known plant flavonoid. Russ. J. Bioorganic Chem. 2009, 35, 376-378. [CrossRef]

92. Zhao, M.H.; Jiang, Z.T.; Liu, T.; Li, R. Flavonoids in Juglans regia L. leaves and evaluation of in vitro antioxidant activity via intracellular and chemical methods. Sci. World J. 2014, 2014. [CrossRef]

93. Materska, M.; Perucka, I. Antioxidant activity of the main phenolic compounds isolated from hot pepper fruit (Capsicum annuum L.). J. Agric. Food Chem. 2005, 53, 1750-1756. [CrossRef]

94. Liu, Z.; Tao, X.; Zhang, C.; Lu, Y.; Wei, D. Protective effects of hyperoside (quercetin-3-o-galactoside) to PC12 cells against cytotoxicity induced by hydrogen peroxide and tert-butyl hydroperoxide. Biomed. Pharmacother. 2005, 59, 481-490. [CrossRef]

95. Hung, T.M.; Na, M.K.; Thuong, P.T.; Su, N.D.; Sok, D.E.; Song, K.S.; Seong, Y.H.; Bae, K.H. Antioxidant activity of caffeoyl quinic acid derivatives from the roots of Dipsacus asper Wall. J. Ethnopharmacol. 2006, 108, 188-192. [CrossRef]

96. Jun, Y.L.; Eun, J.C.; Hyo, J.K.; Jun, H.P.; Sang, W.C. Antioxidative flavonoids from leaves of Carthamus tinctorius. Arch. Pharm. Res. 2002, 25, 313-319. [CrossRef]

97. Kilic, I.; Yeşiloğlu, Y.; Bayrak, Y. Spectroscopic studies on the antioxidant activity of ellagic acid. Spectrochim. Acta Part. A Mol. Biomol. Spectrosc. 2014, 130, 447-452. [CrossRef] [PubMed]

98. Zhou, D.Y.; Sun, Y.X.; Shahidi, F. Preparation and antioxidant activity of tyrosol and hydroxytyrosol esters. J. Funct. Foods 2017, 37, 66-73. [CrossRef]

99. Babaei, H.; Sadeghpour, O.; Nahar, L.; Delazar, A.; Nazemiyeh, H.; Mansouri, M.R.; Poursaeid, N.; Asnaashari, S.; Moghadam, S.B.; Sarker, S.D. Antioxidant and vasorelaxant activities of flavonoids from Amygdalus lycioides var. horrida. Turkish J. Biol. 2008, 32, 203-208.

100. Nazemiyeh, H.; Kazemi, E.M.; Zare, K.; Jodari, M.; Nahar, L.; Sarker, S.D. Free radical scavengers from the aerial parts of Euphorbia petiolata. J. Nat. Med. 2010, 64, 187-190. [CrossRef]

101. Kumar, S.; Prahalathan, P.; Raja, B. Antihypertensive and antioxidant potential of vanillic acid, a phenolic compound in L-NAME-induced hypertensive rats: A dose-dependence study. Redox Rep. 2011, 16, 208-215. [CrossRef] [PubMed]

102. Chethan, S.; Dharmesh, S.M.; Malleshi, N.G. Inhibition of aldose reductase from cataracted eye lenses by finger millet (Eleusine coracana) polyphenols. Bioorganic Med. Chem. 2008, 16, 10085-10090. [CrossRef] [PubMed]

103. Kiliç, I.; Yeşiloğlu, Y. Spectroscopic studies on the antioxidant activity of p-coumaric acid. Spectrochim. Acta Part A Mol. Biomol. Spectrosc. 2013, 115, 719-724. [CrossRef]

104. Kikuzaki, H.; Hisamoto, M.; Hirose, K.; Akiyama, K.; Taniguchi, H. Antioxidant properties of ferulic acid and its related compounds. J. Agric. Food Chem. 2002, 50, 2161-2168. [CrossRef] [PubMed]

105. Gülçin, I. Antioxidant activity of caffeic acid (3,4-dihydroxycinnamic acid). Toxicology 2006, 217, 213-220. [CrossRef]

106. Gordon, M.H.; Roedig-Penman, A. Antioxidant activity of quercetin and myricetin in liposomes. Chem. Phys. Lipids 1998, 97, 79-85. [CrossRef] 
107. Pekkarinen, S.S.; Heinonen, I.M.; Hopia, A.I. Flavonoids quercetin, myricetin, kaemferol and (+)-catechin as antioxidants in methyl linoleate. J. Sci. Food Agric. 1999, 79, 499-506. [CrossRef]

108. Áy, É.; Hunyadi, A.; Mezei, M.; Minárovits, J.; Hohmann, J. Flavonol 7-O-glucoside herbacitrin inhibits HIV-1 replication through simultaneous integrase and reverse transcriptase inhibition. Evid. Based Complement. Altern. Med. 2019, 2019. [CrossRef]

109. Mahmood, N.; Pizza, C.; Aquino, R.D.; Tommasi, N.; Piacente, S.; Colman, S.B.A.S.; Hay, A.J. Inhibition of HIV infection by flavanoids. Antiviral Res. 1993, 22, 189-199. [CrossRef]

110. Kratz, J.M.; Andrighetti-Fröhner, C.R.; Kolling, D.J.; Leal, P.C.; Cirne-Santos, C.C.; Yunes, R.A.; Nunes, R.J.; Trybala, E.; Bergström, T.; Frugulhetti, I.C.P.P.; et al. Anti-HSV-1 and anti-HIV-1 activity of gallic acid and pentyl gallate. Mem. Inst. Oswaldo Cruz 2008, 103, 437-442. [CrossRef] [PubMed]

111. Wijaya, S.J.; Yanuar, A.; Handayani, R.; Syahdi, R.R. In silico analysis of flavonoid glycosides and its aglycones as reverse transcriptase inhibitor. Pharmacogn. J. 2019, 11, 1252-1255. [CrossRef]

112. Akroum, S.; Bendjeddou, D.; Satta, D.; Lalaoui, K. Antibacterial activity and acute toxicity effect of flavonoids extracted from mentha longifolia. Am. J. Sustain. Agric. 2009, 4, 93-96.

113. Rattanachaikunsopon, P.; Phumkhachorn, P. Contents and antibacterial activity of flavonoids extracted from leaves of Psidium guajava. J. Med. Plants Res. 2010, 4, 393-396.

114. Gutiérrez-Larraínzar, M.; Rúa, J.; Caro, I.; de Castro, C.; de Arriaga, D.; García-Armesto, M.R.; del Valle, P. Evaluation of antimicrobial and antioxidant activities of natural phenolic compounds against foodborne pathogens and spoilage bacteria. Food Control. 2012, 26, 555-563. [CrossRef]

115. Rawdkuen, S. Antimicrobial activity of some potential active compounds against food spoilage microorganisms. African J. Biotechnol. 2012, 11, 13914-13921. [CrossRef]

116. Guzman, J.D. Natural cinnamic acids, synthetic derivatives and hybrids with antimicrobial activity. Molecules 2014, 19, 19292-19349. [CrossRef]

117. Borges, A.; Ferreira, C.; Saavedra, M.J.; Simões, M. Antibacterial activity and mode of action of ferulic and gallic acids against pathogenic bacteria. Microb. Drug Resist. 2013, 19, 256-265. [CrossRef]

118. Giordani, R.; Trebaux, J.; Masi, M.; Regli, P. Enhanced antifungal activity of ketoconazole by Euphorbia characias latex against Candida albicans. J. Ethnopharmacol. 2001, 78, 1-5. [CrossRef]

119. Martos, S.; Spanò, D.; Agustí, N.; Poschenrieder, C.; Pintus, F.; Moles, L.; Medda, R. A chitinase from Euphorbia characias latex is a novel and powerful plant-based pesticide against Drosophila suzukii. Ann. Appl. Biol. 2017, 171, 252-263. [CrossRef] 